\title{
The Histochemistry of Ceroid and Ceroid Like Pigment
}

\author{
Ryuei MAEdA \\ Department of Pathology, Kansai Medical School, Moriguchi, Osaka
}

It was found that vitamin $\mathrm{E}$ deficient rats exhibit a brownish pigment accumulation in macrophages in the smooth muscle layer of the uterus (Martin and Moore, '36, '38). The name ceroid was given by Lillie et al. ('42) to a yellow, acid-fast, iron-free pigment occurring in the experimental cirrhotic livers of rats. Wolf and Pappenheimer ('45) described the occurrence of a ceroid-like pigment by virtue of its acid-fastness in various human tissues. Endicott and Lillie ('44) described the main characteristics of ceroid pigment and the means of distinguishing it from other lipopigment such as lipofuscins, however, subsequently it was pointed out that the properties of acid-fastness, Schmorl's test as well as chrome alum hematoxylin stain are shared by some of lipofuscins. These findings mean that these methods cannot be used to distinguish between both the pigment.

In a previous paper distinction could be made by a positive reaction of ceroid with a $0.05 \%$ nile blue sulphate stain ( $\mathrm{pH} 2.5$ to 3.0 ). It should be noted that ceroid is colored emerald green with a leuco-malachite green staining which was reported in this 6th General Meeting of the Japanese Histochemical Association, while lipofuscins gave a negative reaction with the above method.

On the other hand, as shown in Table 1, ceroid could be devided into two types; the one is liver-type ceroid showing a positive reaction with a sudan stain etc. and the other is ovary-or aorta-type ceroid giving a stronger positive reaction with a sudan stain etc. (Table 1 ).

Next, both the sudanophilia and NAHD (2-hydroxy-naphthoic acid hydrazide tetrazotized o-dianisidine) reaction of ceroid in paraffin sections are abolished by the peracetic acid oxidation followed by methylation, but a strong positive reaction of ceroid with the periodic acid Schiff reaction as well as with Sudan black B stain is unaffected by the same procedure. Accordingly, it is reasonably suggested that these two methods indicate the histochemical characteristics of both ceroid and of the cytoplasm of macrophages containing the pigment. On the other hand, it is considered to give a important information for the mechanism of the NAHD reaction that ceroid is colored blue-purple, as it is, with the NAHD reaction after the periodic acid oxidation followed by a treatment with $\mathrm{m}$-aminophenol which has been recently adopted by Lillie et al. ('61), as one of the most effective blocking reagent being colored red-brown with tetrazotized o-dianisidine after the same treatment, while it offers the negative Schiff reaction after the above pre-treatment, and that a treatment with 2-hydroxy-3-naphthoic acid hydrazide following the periodic acid oxidation 
Table 1 Comparative histochemistry of ceroid and lipofuscins

\begin{tabular}{|c|c|c|c|}
\hline \multirow{2}{*}{ methods } & \multicolumn{2}{|c|}{ ceroid } & \multirow{2}{*}{$\begin{array}{l}\text { lipofuscins } \\
\text { heart muscle } \\
\text { liver cells }\end{array}$} \\
\hline & liver & aorta, ovary & \\
\hline Sudan III in paraffin sections & $+\sim m$ & $H \sim H$ & $H$ \\
\hline Sudanblack B in paraffin sections & $H \sim H$ & H & H \\
\hline PAS & $\mathrm{H}$ & Hit & $H$ \\
\hline NAHD & $H$ & 世 & $H$ \\
\hline Acid-fast fuchsin & $+\sim H$ & H & $\div \sim+$ \\
\hline Toluidine blue at $\mathrm{pH} 7.0$ & H & H & H \\
\hline Nile blue sulphate at $\mathrm{pH} 3.0$ & $H \sim H$ & m & $\div \sim+$ \\
\hline "Mercury-affine* reaction" & - & H & - \\
\hline Alkaline silver & $t \sim t+$ & H & $+\sim H$ \\
\hline Aldehyde-fuchsin & H & tt & H \\
\hline Chrome alum hematoxylin & $-\sim+$ & $-\sim+$ & - \\
\hline Schmorl & $-\sim+$ & $-\sim+$ & - \\
\hline Peracetic acid-Schiff & + & + & + \\
\hline Leuco-malachite green & H & $H$ & $\div$ \\
\hline
\end{tabular}

* A modified procedure of Okamoto et al. method for phospholipids that is based on combination of divalent mercury with unsaturated $\mathrm{C}=\mathrm{C}$ bonds of lipid substances.

Table 2

\begin{tabular}{|c|c|c|}
\hline & reaction in paraffin sections & ceroid \\
\hline & NAHD reaction & H (blue-purple) \\
\hline \multirow{5}{*}{ 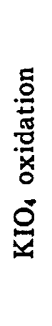 } & Schiff reaction & $H($ red $)$ \\
\hline & $\begin{array}{l}\text { Schiff reaction after a treatment with } 2 \text {-hydroxy-3- } \\
\text { naphthoic acid hydrazide }\end{array}$ & $H$ (red) \\
\hline & $\begin{array}{l}\text { tetrazotized o-dianisidine after a treatment with } \mathrm{m} \text { - } \\
\text { aminophenol }\end{array}$ & H (red-brown) \\
\hline & NAHD reaction after a treatment with $\mathrm{m}$-aminophenol & H (blue-purple) \\
\hline & Schiff reaction after a treatment with $\mathrm{m}$-aminophenol & - \\
\hline
\end{tabular}

in paraffin sections failed to prevent the positive Schiff reaction revealed successively by ceroid (Refer to Table 2).

Besides, the present author, observing that yellow pigment granules ("adrenal pigment") occurring at an average rate of approximately 66 per cent in the lining cells of sinuses in the zona reticularis of normal animal adrenal glands excluding human ones are histochemically identical with ceroid, suggested that the pigment of brown degeneration of the adrenal gland caused by an excessive dietary lanolin feeding for rabbits and guinea pigs or the repeated administration of sex hormones for rats and mice, might be due to an increase in amount of "adrenal pigment".

Since Hass ('39), subsequently Endicott ('44) described the appearance of the insoluble products in the site of injection following the subcutaneous administration of lipid substances, for example cod-liver oil, classified in general 
as auto-oxidizable compounds possessing the ethylenic linkages in the long chain of fatty acids, the most likely explanation is that ceroid occurring in case of deficiency of vitamin E, an effective antioxidant in the fat tissue, possibly consists of polymers of the oxidized fatty acids so highly polymerized that they are insoluble in fat solvents.

It has been already reported that ceroid-like products can be formed both in vitro and in vivo following prolonged contact of red blood cells or other substances with unsaturated fat substances (Hartroft, '51, Casselman, '51, Tappel, '55). However, it is observed by the present author that nile blue sulphate solution at pH 3.0 stains pink ceroid-like substances derived from the subcutaneous tissue as well as from fats of the adrenal cortex fixed with Tellyesniczky's fluid. Morever, in the several series of rats fed (1) a high fat diet, (2) a low protein diet, (3) an excess of dietary cystine, (4) a high fat diet, deficient in choline, (5) a low protein, high fat diet, deficient in vitamin E, (6) a low protein, high fat diet containing an excess of dietary cystine, no correlation could be found between the amount of ceroid and that of fats, especially of unsaturated ones demonstrable in their fatty livers. Similar results were obtained in fatty livers in autopsy cases.

Further, it has been clarified by means of making a more strict analysis of the various experimental conditions in which ceroid has been produced, that ceroid is very closely related to hemosiderin in several series of animals adopted. Table 3 shows the relationship between ceroid and hemosiderin in three series of rats which were (1) reared on a vitamin E deficient diet, (2) kept on an excessive dietary cystine, (3) poisoned with carbon tetrachloride inhalation.

Table 3

\begin{tabular}{|c|c|c|c|c|c|c|}
\hline \multirow{2}{*}{ Groups of animals } & \multicolumn{2}{|c|}{$\begin{array}{c}\text { Experimental } \\
\text { animals }\end{array}$} & \multicolumn{2}{|c|}{$\begin{array}{l}\text { Cases showing a } \\
\text { deposit of ceroid } \\
\text { in the liver }\end{array}$} & \multicolumn{2}{|c|}{$\begin{array}{l}\text { Cases showing both ceroid } \\
\text { and hemosidern deposition } \\
\text { in individual macrophages } \\
\text { in the liver }\end{array}$} \\
\hline & Species & Number & Number & $\left|\begin{array}{c}\text { Percentage } \\
\text { (per total } \\
\text { number) }\end{array}\right|$ & Number & $\begin{array}{l}\text { Percentage } \\
\text { (per number of } \\
\text { ceroid-positive } \\
\text { cases) }\end{array}$ \\
\hline \multirow{2}{*}{$\begin{array}{l}\text { Groups kept on a } \\
\text { vitamin E deficient } \\
\text { diet }\end{array}$} & rats & 30 & 16 & 53 & 14 & 88 \\
\hline & mice & 15 & 9 & 67 & 9 & 100 \\
\hline $\begin{array}{l}\text { Groups kept on an } \\
\text { excess of dietary } \\
\text { cystine }\end{array}$ & rats & 8 & 7 & 88 & 5 & 70 \\
\hline \multirow{2}{*}{$\begin{array}{l}\text { Groups poisoned } \\
\text { with carbon } \\
\text { tetrachloride }\end{array}$} & rats & 10 & 6 & 60 & 6 & 100 \\
\hline & mice & 14 & 12 & 85 & 11 & 92 \\
\hline
\end{tabular}

As indicated in this table, as many as 70 to 100 per cent of the total animals which presented a deposit of ceroid in their livers, showed both ceroid and hemosiderin deposition in individual macrophages in their livers. In addition, because the iron reaction of ceroid itself usually is negative, it is very likely that ceroid can be in vivo derived from the stroma of erythrocytes.

On the basis of these findings, the following experiments were undertaken 


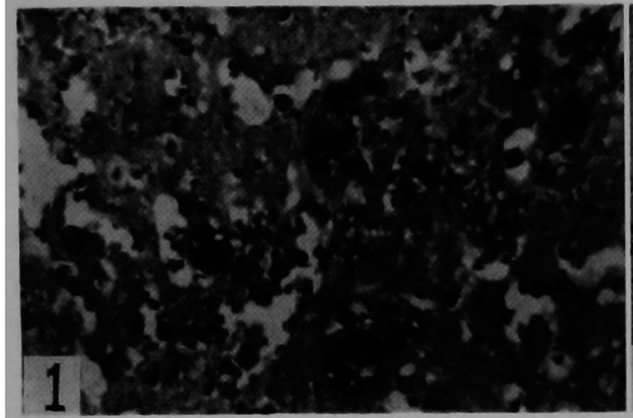

Fig. 1 .

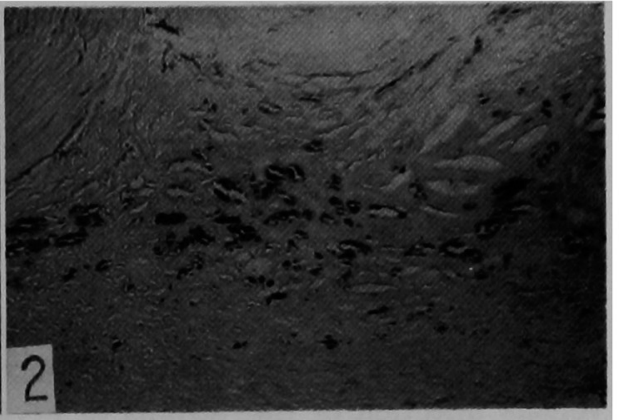

Fig. 2.

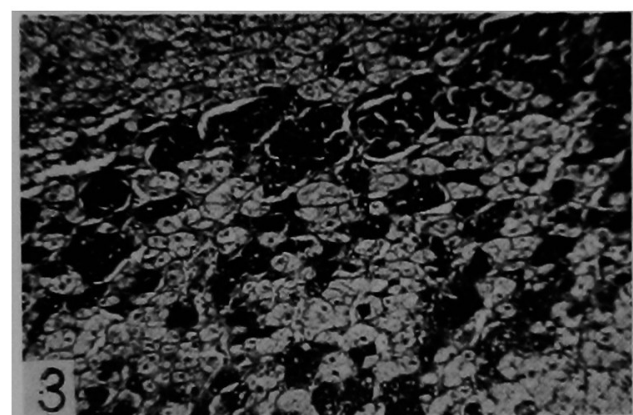

Fig. 3.

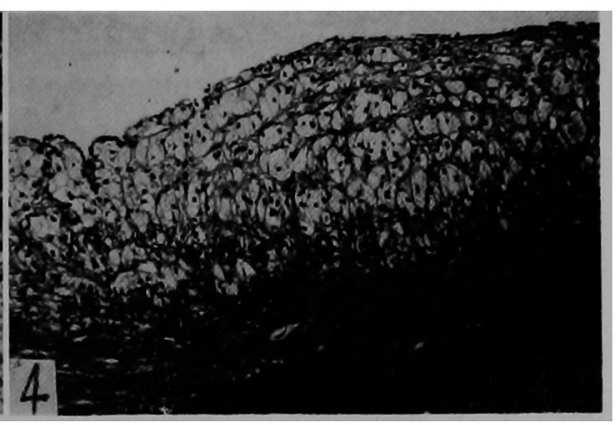

Fig. 4 .

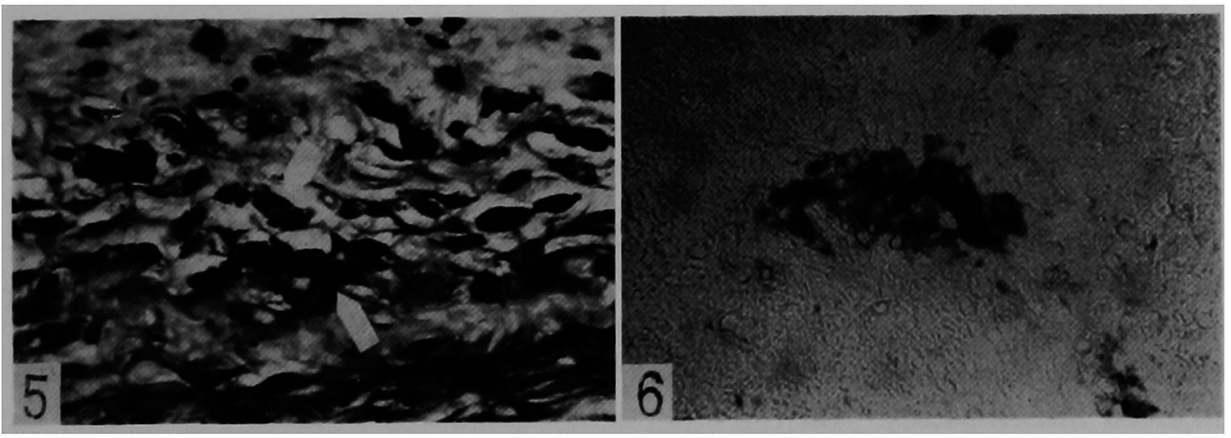

Fig. 5.

Fig. 6 .

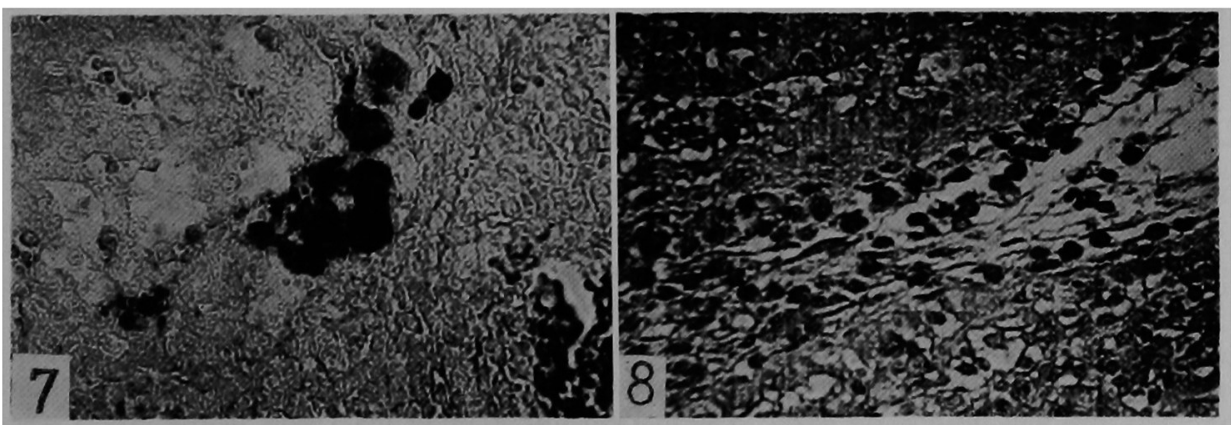

Fig. 7 .

Fig. 8. 
for the purpose of confirming the origin of ceroid; a suspension of the stroma of erythrocytes prepared by adding the fourfold physiological saline solution has been injected interavenously into thirty-five normal Wistar strain rats. Animals were sacrificed one after another at intervals of one or more days after the administration of a dose of two $\mathrm{ml}$. of the suspension to each animal.

Consequently in their lymph nodes, particularly in paraaortic lymph nodes a substance, histochemically identical with ceroid was demonstrated within many macrophages, however, in their livers, spleens, and lungs ceroid-like pigments were scarcely found. For example, two or three days after the intravenous injection of the stroma of erythrocytes, ceroid-like pigment was observed in a fairly large number of macrophages in rat lymph nodes as a sudanophilic substance in paraffin sections. Four to twelve days after the intravenous injection most of the ceroid-like pigments was found to co-exist with hemosiderin in individual macrophages in the lymph nodes. In control rats of the Wistar strain no ceroid-like pigment was observed in their lymph nodes. Based on the fact that the findings quite similar to those observed in the above experiments have been recognized in the lymph nodes in rats kept on a vitamin $\mathrm{E}$ deficient diet, it should be assumed that ceroid in the lymph nodes in case of vitamin E deficiency might be also derived from the stroma of erythrocytes.

Further confirmation of these views will be made by the simultaneous production of both ceroid and hemosiderin in individual macrophages in the lymph nodes or elsewhere in another groups of animals exclusive of vitamin E deficient rats. It is of considerable interest to assume that the lipid component of ceroid might be derived from the protein-bound phospholipid, cholesterol and cerebrosides constantly contained in the stroma of erythrocytes. Then, the question arises; why only a relatively small amount of ceroid is formed in the site of injection after a larger amount of a suspension of red cell envelopes is injected into the subcutaneous tissue. It is reasonable to assume that it might be attributable to the factor that a high proportion of a suspension of red cell envelopes is quickly absorbed from there and disappears. Similar explanation might be applicable to the fact that ceroid is scarcely formed in the liver, spleen and lung when a suspension of red cell envelopes has been injected intravenously. On the other hand, a marked formation of ceroid in the lymph nodes might be due to their capacity of retaining red cell envelopes that have been possibly hematogenously or lymphogenously brought into the lymph nodes.

\section{Explanation of Figures}

(all sections used were paraffin-embedded).

Fig. 1. Liver section of the rat reared on a vitamin $\mathrm{E}$ deficient during 294 days. Leucomalachite green staining. Dark globules indicate a positive reaction. $\times 400$.

Fig. 2. Portion of atheromatous changes in aorta in an autopsy case of lung cancer with arteriosclerosis. "Mercury affine reaction". Dark granules indicate ceroid. $\times 100$.

Fig. 3. Portion of the marked thickening of the intima in aorta of a rabbit fed the high fat diet during 119 days. The marked formation of foam cells in the intima was observed, however, no ceroid was demonstrated in foam cells or elsewhere in aorta. 
Sudan black B stain. $\times 100$.

Fig. 4. Adrenal section of the same animals as those shown in Fig. 3. Note brown degeneration in the zona reticularis. Sudan black B stain. $\times 400$.

Fig. 5. Portion of rat subcutaneous tissue showing a relatively small amount of ceroid-like pigments observed in the site of injection, two weeks after the adminstration of a fairly large amount of a suspension of red cell envelopes. Arrows show ceroidlike pigments. Nile blue sulphate stain. $\times 400$.

Fig. 6. Portion of rat lymph node showing a considerable amount of ceroid co-existing with hemosiderin in individual macrophages, six days after the intravenous administration of a suspension of red cell envelopes. Sudan III stain and iron reaction. Dark granules indicate hemosiderin, while lesser dark ones show ceroid. $\times 400$.

Fig. 7. Portion of the lymph node of a rat reared on a vitamin E deficient diet for 294 days. There is found ceroid co-existing with hemosiderin in individual macrophages. Note the finding indistinguishable from Fig. 6. Sudan III stain and iron reaction. $\times 400$.

Fig. 8. Portion of rat lymph node showing ceroid-like substances existent in many macrophages, two days after the administration of a red cell envelopes. Sudan III stain and iron reaction. $\times 400$.

\section{References}

1) Adams, C.W.M., J. Path. \& Bact., 77, 648, $1959 . \quad$ 2) Adams, C.W.M., Bayliss, O.B., and Ibrahim, M.Z.M., J. Histochem. \& Cytochem., 11, 560, 1963. 3) Ashbel, R., and Seligman, A.M., Endocrinology, 44, 565, 1949. 4) Barrnett, R.J., and Seligman, A.M., J. Histochem. \& Cytochem., 4, 411, 1956. 5) Blumberg, H., and Grandz, H.G., Arch. Path., 34, 1035, 1942. 6) Bonhag, P.F., J. Morphol., 96, 381, $1955 . \quad 7$ ) Burrowo, H., J. Path. \& Bact., 51, 385, $1940 . \quad$ 8) Burstone, M.S., J, Histochem. \& Cytochem., 3, 32, $1955 . \quad 9$ ) Burstone, M.S., Enzyme Histochemistry, Academic Press, New York \& London, 1962.110$)$ Casselman, W.G.B., J. Exper. Med., 94, 549, 1951. 11) Cramer, W., and Horning, E.S., Lancet, 1, 247, $1936 . \quad 12)$ Dam, H., J. Nutrit., 27, 193, 1944.13 13) Edwards, J.E., and Dalton, A.J., J. Nat. Cancer Inst., 3, 19, $1942 . \quad$ 14) Endicott, K.M., Arch. Path., 37, 49, 1944. 15) Endicott, K.M., and Lillie, R.D., Am. J. Path., 20, 149, $1944 . \quad 6)$ Firminger, H.I., J. Nat. Cancer Inst., 13, 225, 1952. 17) Gedick, P. und Fischer, R., Virchows Arch., 332, 431, 1959. 18) György, P., and Goldblatt, H., J. Exper. Med., 89, 245, 1949; 90, 73, 1949. 19) György, P. and Rose, C., Science, 108, 716, 1948. 20) Hamperl, H., Virchows Arch., 318, 32, 1950. 21) Hartroft, W.S., Science, 113, 673, 1951. 22) Hass, G.M., Arch. Path., 28, 177, $1939 . \quad 23)$ Lee, C.S., J. Nat. Cancer Inst., 11, 339, 1950.24 ) Lillie, R.D., Stain Technol., 27, 37, 1952; 31, 151, 1956. 25) Lillie, R.D., J. Histochem. \& Cytochem., 2, 127, $1954 ; 4,377,1956 ; 6,130,1958$. 26) Lillie, R.D., Ashburn, Z.L., Sebrell, W.H., Daft, F.S., and Lowrey, J.V., Pub. Health Rep., 57, 502, $1942 . \quad 27)$ Lillie, R.D., and Baugle, R.Jr., J. Histochem. \& Cytochem., 2, 300, 1954. 28) Lillie, R.D., Gilmer, P.R. Jr., and Welsch, R.A., Stain Technol., 36, 361, 1961. 29) Lison, L., Zieglers Beitr., 101, 94, 1938. 30) Maeda, R., and Takada, R., Tr. Soc. Path. Jap., 46, 384, $1957 . \quad 31)$ Maeda, R., Takada, R., Hagihara, T., and Yamagata, I., The 6th General Meeting of the Proc. Jap. Histochem. Ass., October 18, $1965 . \quad 32$ ) Maeda, R., Takada, R., and Yamagata, I., Folia endocrinol. Jap. 37, 487, 1961. 33) Martin, A.J.P., aud Moore, T., Chemistry add Industry, 14, (J. Soc. Chem. Indust., 55), 236, 1936 ; Chemistry and Industry, 16 (J. Soc. Chem. Indust., 57), 973, 1938. 34) Mason, K.E., and Emmel, A.F., Anat. Rec., 92, 33, $1945 . \quad 35)$ Morrison, R.W., and Hack, M.H., Am. J. Path., 25, 597, 1949. 36) Mukherjo, M., Deb, C., and Sen, P.B., J. Histochem. \& Cytochem., 10, 83, $1962 . \quad 37)$ Okamoto, K., Shimamoto, T., Ueda, M., Kusumoto, Y., and Shibata, D., Bull. Kobe Med. College, 3, 1, $1952 . \quad 38$ ) Pappenheimer, A.M., and Victor, J., Am. J. Path., 22, 395, $1946 . \quad 39)$ Pearse, A.G.E., Histochemistry, Theoretical and Applied, 2 Ed., Churchill \& London, 1961. 40) Popper, H., György, P., and Goldblatt, H., Arch. Path., 37, 161, $1944 . \quad 41)$ Schmidt, R., Virchows Arch., 323, 9, $1953 . \quad$ 42) Schornagel, H.E., J. Path. \& Bact., 72, 267, $1956 . \quad$ 43) Takada, R., Tr. Path. Jap., 49, 1035, $1960 . \quad 44)$ Tappel, A.L., Arch. Biochem. Biophys., 54, 266, 1955. 45) Tobin, C.E., and Birubaum, J.P., Arch. Path., 44, 269, $1941 . \quad 46)$ Victor, J., and Pappenheimer, A.M., J. Exper. Med., 82, 375, $1945 . \quad 47)$ Wolf, A., and Pappenheimer, A.M., J. Neuropath. Exp. Neurol., 4, 402, 1945. 